\title{
The Accurate Eight Classes of the Grammarians of Basra and Kufa Analytical, Historical Study
}

\author{
Dr. Basem Abed Al-Rahman Al-Bably
}

Department of Arabic Language - Faculty of Arts Islamic University of Gaza - Palestine

\begin{abstract}
The study aims at determining suitable criteria in classifying the grammarians of Kufa and Basra Schools, which depend on the studentship as a criterion to classify the grammarians in order to eliminate the existing confusion in the books of classifications and biographies. The researcher manages to identify the criterion of classifications with extra determinants stemming from the studentship, which makes an access to a perfect perception in the classifications of the grammarians in Kufa and Basra. Moreover, the researcher concentrates on identifying the grammarian and his student, strictly following the consensus of all related references, and leaving biographizing the élite to the specialized books of biography and other historical references.
\end{abstract}

Keywords: Arabic Language, Grammar, Arab Grammarians, Class, Kufa, Basra.

\section{The Previous Studies for the Grammarians' Classes, and the Linguists who ARE A PART OF THESE CLASSES}

First: The former linguists: the references which are about the grammarians classes do not consider an identified method in dividing the classes as much as they concentrate on the biography of the linguists and grammarians. Their methods vary as the following:

- Marateb Al-Nahawieen by Abu Al-Tayeb Al-Loughawy(the linguist) (d. $351 \mathrm{H}$ ); it starts with Abi Al-Aswad whose students were Atta, Yahya, Mymoun, Anbasa, Ibn Abi Isaac, Ibn Alaa, Issa Ibn Omar, Younis, Abu Al-Khatab, Omar Al-Rawya ( the narraror), AL-Rou'asy who learnt from Aby Amro, and then Asem Al-Qare' (the reader), Ibn Mohesan, Yahya Ibn Ya'mor, Al-Zyat, AlKhaleel Ibn Ahmed ... etc. The classification adopted by Abu Al-Tayeb is in opposition to the Biographers. Moreover, there is no consistent criterion in classifying the linguists, yet he brackets between Issa , Abu Al-Khatab, and Younis together as the same sheikhs ( the linguist teachers) for Abu Zayd, Abu Obiada, and Al-Asmay. I support this combination of the linguist teachers for some reasons I will mention later!

- Akhbar Al-Nahwieen Al-Basrieen by Abu Said Al-Serafy (d. $368 \mathrm{H}$ );he outlined his method in his book's introduction. He wrote, "In it there are the famous grammarians, their stories, learning from each other, and the first pioneers in Grammatology."

Al-Serafy placed the students of Abu Al-Aswad in one class: Yahya, Anbasa, Mymoun, and Nasr, and he biographized Nasr, and Ibn Hermez ......... Then the writer brackets Bymiun and Ibn Abi Isaac together in the biography. After that he biographized Abu Amro, and Isaa, declaring that Isaa was in the class of Abu Amro andlearnt from Ibn Abu Isaac. This classification is not approved and I will mention that later. Also, he biographized Younis who was a student of Abu Amro; then he moved to Al-Khaleel ... etc.

- Tabaqat Al-Nahwieen and Al-Lougawieen by AL-Zobydy ( d. $3789 \mathrm{H}$ ); he explained his method in the introduction, saying " the classes were classified according to their time, countries, schools, ranks, births, ages, life period, and their dates of death as possible, with biographizing them." ${ }^{2}$. At

\footnotetext{
${ }^{1}$ Akhbar Al-Nahwieen Al-Basrieen, p.10

${ }^{2}$ Tabaqat Al-Nahwieen and Al-Lougawieen, p 17-18 
first, he started with the grammarians, then the linguists, and regarding the grammarians, he started with Basra school (Al-Basrioon), then Al-Koufa School ( Al-Koufioon). In the lingusits' section, the writer started with Basra School, then Al-Koufa School. After that, he mentioned the Egyptian, provincial, Andalusian grammarians and linguists.

AL-Zobydy put Abu Al-Aswad and Ibn Hermez in the first class which identifies the commencement of grammatology. That classification is opposed to all the historians, and he tended to that classification because of the precedence of Ibn Hermez. The class two includes Nasr, Yahya, Anbasa, and Mymoun who all have the same rank because they all learnt from the same grammarian, Abu- $\mathrm{Al}$ Aswad, and the next class includes Ibn Abi Aqrab and Ibn Abi Isaac. Also, he put Ibn Al-Alaa and his brother, Al-Akhfash Al-Akbar, and Issa Ibn Omar in the fourth class. When he reached the fifth class, he put Al-Khaleel at the head of it. Some classes in this book were not organized.

- Tareekh Al-Olamaa AL-Nahwieen Min Al-Basrieen and Al-Koufieen and Others by the Judge Abu Al-Mahasen Al-Mofadal Al-Tanoukhy Al-Maary ( d. $442 \mathrm{H})$. His method in classifying the grammarians depends on the division into Al-Basrioon and Al-Koufioon; he started with his contemporariesuntil he reached the first grammarians in every school.

Abu Al-Aswad was the last one whom the author mentioned, and he put his students at the head of the class: Ibn Hermez, Mymoun, Anbasa, Nasr; and he classified them as the students of Abu Al-Aswad. Clearly, he did not mention Yahya in that class, because he placed him in other classification which includes Yahya, Ibn Abi Isaac, Abu Amro, and Isaa who "are at the same epoch, and are very famous". I think the writer there meant the contemporariness not the studentship. In the biography of Isaa, the author wrote " he was authorized by Abu Amro." In addition, in other positions, the writer mentioned who were at the time of the famous grammarians. ${ }^{4}$ He biographized Isaa after the other three grammarians, and the writer put Al-Khfash Al-Akbar before Isaa, then he biographized Isaa, then Al-Khaleel, Younis, Al-Yazydy, Sebaweeh, Al-Khfash Al-Awsat, and even the grammarians in the author's era.

His method in classification does not demarcate the rankship as much as it shows his concern with the classification according to the studentship. Despite that, he did not manage to classify Yahya, Isaa, Ibn Abi Isaac, and Abu Amro.

- Nozhat Al-Albaa Fi Tabaqat Al-Odabaa by Abu AL-Barakat ( d. $577 \mathrm{H}$ ); he explained that he would be talking about the leading authorities on grammatology and those who were similar to them. He started with Ali (May Allah Be Pleased With Him), and then he biographized Abu AlAswad Al-Dou'ly who was followed by his students: Anbasa, Mymoun, Nasr, Ibn Hermez, and Yahya Ibn Yamor. ${ }^{5}$ After that he biographized Ibn Abi Isaac (d. $117 \mathrm{H}$ ) without mentioning that he was in a new class and mentioning his students. Isaa Ibn Omar (d. $149 \mathrm{H})$ was put after him and Ibn Abi Amro (d, $154 \mathrm{H}$ ) are placed next according to the date of death. Then he mentioned Abu Mouawiya Shyban ( d. 164 H) and Abu Abedallah Haroun, then Al-Qatamy Al-Koufy, Hamad AlRawya, and Hamda Ibn Salama (d. 169 H). Next, Al-Khfash, then Al-Khaleel, then Younis and Al-Rou'asy... etc. He put Al-Kesaey after Sebaweeh. Apparently, his method in classification follows the contemporariness and the date of death, then the school, without any consideration for studentship and learning.

- Inbaa Al-Rwaa Ala Anbaa Al-Nouhaa by Al-Qfty ( d. $624 \mathrm{AH}$ ); he mentioned the leading grammarians from the east and west of all the Islamic countries and he arranged them alphabetically in order to be within reach. ${ }^{6}$ At the beginning of his book, he mentioned the sheikh and the student: Nasr learnt from Abi Al-Aswad, Abu Amro from Nasr, Al-Khaleel from Abu Amro, and Sebaweeh from Al-Khaleel ... etc.

Tabaqat Al-Nohaa Wa Al-Loghawieen by Ibn Gady Shahba (d. 851 AH); he cared about the biography without dividing it into time classes or scientific classes. He classified the grammarians and linguists alphabetically (Ibraheem, 1979), so the clasship is not adopted.

\footnotetext{
${ }^{3}$ Tareekh Al-Olamaa AL-Nahwieen, p 135

${ }^{4}$ Tareekh Al-Olamaa AL-Nahwieen, $\mathrm{p} 138$

${ }^{5}$ Nozhat Al-Albaa, p 22

${ }^{6}$ Inbaa Al-Rwaa Ala Anbaa Al-Nouhaa, p 37
} 
SECOND: The latter grammarians: their methods vary as the following:

- Al-Madares Al-Nahwiya by Dr. Shawqi Deif; he did not identify the classes, but he mentioned the grammarians and their students. In addition, he discussed the emergence of grammatology and the leading grammarians who contributed to his scientific theory; he and the previous grammarians had the same perceptions regarding the establishment of grammatology. Ali (May Allah Be Pleased With Him) was the first founder, then Abu Al-Aswad, then his students. In opposition to many references, he did not list Ibn Abi Isaac in that previous chain; he made him the sheikh (this word sheikh, means that the person is expert at any subject he/she studies) of Abu Al-Alaa, Isaa and Younis, but he placed Isaa before Ibn Al-Alaa. Next, he mentioned Al-Akhfash , the sheikh of Younis and Sebaweeh, and then he biographized Al-Khalel before Sebaweeh. ${ }^{7}$

- Akhbar Al-Nahwieen Al-Basrieen L-Serafy edited by Abed Al-Mina'm Khafajy and Taha Al-Zyty ${ }^{8}$; the classes are presented differently. The first class includes Nasr, Ibn Hermez, Anbasa, Ibn Abi Isaac, and Yahya; the second class includes Isaa, Abu Amro, Al-Akhfash Al-Kabeer; the third class, Al-Khalel and Younis; the fourth class, Sebaweeh, Al-Yazeedy, Al-Nadr, Qoutreb, Al-Khfas Al-Awsat, Abu Obiada, Abu Zayd, Al-Asmay, and Ibn Salam. Next he wrote the fifth and sixth class, and then he moved to Al-Koufioonclasses , then to Al-Baghdadioon, then to grammarians of Iraq and Faris...

- Al-Moufeed Fi Al-Madares AL-Nahawiya by Ibraheem Al-Samera'i'; he adopts criteria different from Al-Basrioon's in classifying the Basri, Kufi, and Bghdadi schools. The classification depends on the geographical position of the grammarian (in which region); he wrote the classes according to the political dimension in the area: Fatimid class, then Ayyubid class, Mamaleek class. Next, he moved to the late grammarians class.

Al-Samaera'i's certeria in classifying the Kufi and Basri schools depend on the geographical position of grammarians, fanaticism based on learning-from and theory of the establishment of the grammatology, the judgment on the poets and rhetoric experts. He placed the students of Abu AlAswad in the first class for Basrioon; the last student died in $129 \mathrm{AH}$. In the second class, he put Abedallah Ibn Abi Isaac (d. 117 AH) - he was the first - , then he placed Isaa Ibn Omar (d. 149 AH) and Abu Amro Ibn Al-Alaa(d. $154 \mathrm{AH})$ in the same second class. In addition, Abed Al-Rahman Ibn Hermez died in the same year (d. $117 \mathrm{AH}){ }^{10}$

- Min Tareekh Al-Nahw by Said Al-Afghany; his creteria used in classification might be the most accurate because he employs the studentship as a main principle in the classification. Firstly, he started with Abu Al-Aswad, and then his students: Anbasa, Maymoun, Nasr, Yahya, Atta , and Abu Nawfal. After that, he mentioned the students of Abu Al-Aswad's students; he placed Abu Amro and Ibn Abi Isaac without any one in a class. I agree with the writer in that. Nonetheless, the writer hesitated in putting Isaa Ibn Omar alone in a class or putting him in the class of Ibn Al-Alaa and Ibn Abi Isaac. Here I disagree with him for some considerations I will discuss later. However, he placed him - in an explanatory table - ,Abu Zaya, Al-Khafash AL-Akbar, Younis, and AlRou'asy in a class, which is in contrary with his detailed explanation that he mentioned after that classification. ${ }^{11}$ Also, I disagree with him for some considerations that will be written later in detail. For example, he brackets the sheikh and his student together in one class based on the studentship in the classification, which makes the writer place the grammarian in two classes or more. Strictly speaking, he was supposed to use another criterion ( in addition to the studentship) to completely prepare the class without any flaw; therefore, the student and the sheikh will not be in the same class even if both of them, the student and the sheikh, studied under the same teacher, for instance, Al-Khaleel and Sebaweeh were educated by Isaa Ibn Omar; Al-Kesaey and Al-Faraa by AlRou'asy, and others. Clearly, they were educated by the same teacher, but one of them became a

\footnotetext{
${ }^{7}$ Al-Madares Al-Nahwiya, p 11-60

${ }^{8}$ Akhbar Al-Nahwieen Al-Basrieen, p 5-9

${ }^{9}$ Al-Moufeed fi Al-Madares AL-Nahawiya, p 185-6

${ }^{10}$ Al-Moufeed fi Al-Madares AL-Nahawiya, p 29-47

${ }^{11}$ Min Tareekh Al-Nahw, p 33-39
} 
teacher of the other. Thus, that will prevent them from being in one class, and so the student will be placed after his teacher in the classification.

- Al-Madares Al-Nahwya by Dr. Khadeeja Al-Hadeethy ; when she wrote about Al-Basra, she started with Abu Al-Aswad, then his students. After that, she discussed Ibn Abi Isaac and Issa, then Ibn Al-Alaa, then Younis, then Al-Khaleel ... etc. She was not interested in placing them on distinctive classes; she only focused on the mere existence of the schools and their leading authorities. ${ }^{12}$

- Tabaqat Al-Nahawieen Wa Al-Loughwieen:Analytical Study by Sadeq Abu Suliman and Abedallah Ismael; they seek to examine books of the grammarians and linguists classes, and study their importance, methodologies, contents, styles, and their impacts on the contemporary grammarians ... etc. It is clear that the two researchers did not classify the grammarian because they have a different aim for their study.

\section{THE AFOREMENTIONED CRITERIA}

Studying all the historical and contemporary references, I came to the conclusion that the authors had employed different methodologies in dealing with the "class" term; some used the historical chronology in classifying the grammarians and linguists; the others used the biography, or only the date of death, or both the date of death and studentship, or the alphabetic order (the real names not the nicknames).

In their study, Dr. Sadeq and Dr. Ismael asserted that not being bound by the clasship will lead us to say that the late books of grammarians classes are only sheer biography books, for example, AlFihrist, Mu'jam al-Odaba, Wafayat al-Ayan., but calling them as classes books is for knowledge extension, unlike the real classes books of Al-Zoubydy and Abu Al-Tayb Al-Loughwy(the linguist). ${ }^{13}$

\section{SUMMARY}

To classify the early sheikhs in classes needs a steady criterion that is compatible with the goal of classification. The goal is to keep the honor for the first masters of grammatology, to place them at the beginning of the class if they deserve that, and to place them at the end of the class if they deserve that. Therefore, the aim is not their influence on the grammatology as a whole but on being the first who have the knowledge and spread it to the others.

\section{THE RESEARCHER's OPINION ON THE CORRECT STANDARDS IN ClaSSIFYING}

To unify the standards in classifying the grammarian is a must; and it should be adopted in all ages by applying the following suggested criteria:

- Studentship: it includes the following conditions

1. The student does not transcend his teacher, which is the main standard of classes. "The fame of the grammarian is represented by the large amounts of his books and of the narrations sourced to him" ${ }^{14}$.Learning and knowledge transmission from the teacher is the root of the studentship and classification standard.

2. Two students should not be placed in one class if one of them is a teacher of the other such as the grammarians of the third class: Al-Khfash, Younis, and Isaa, and the grammarians of the fourth class: Al-Khlaleel, Abu Zayd, and Al-Asmay.

3. A sheikh and a student of another sheikh (who is at the same class of that sheikh) do not come together in one class like Abu Amro Ibn Alaa and Isaa Ibn Omar, the student of Ibn Abi Isaac, because Abu Amro and Ibn Abi Isaac ( the sheikh of Isaa ) are in the same class.

4. If the sheikh of any grammarian is not known, those grammarians should be classified in a class before the class of their famous students. For example, Mou'az Al-Haraa has unknown sheikh, so he was placed in a class before Al-Kesaey Class.

\footnotetext{
${ }^{12}$ Al-Madares Al-Nahwya, p 74-7

${ }^{13}$ Tabaqat Al-Nahawieen wa Al-Loughwieen: Analytical Study, p 13-14

${ }^{14}$ Marateb Al-Nahwieen, p 85
} 
5. If the grammarians become the student and the teacher at the same time, theywill be classified in one class unless there is another standard that might distinguish between them. For instance, AlRyashy and Al-Mazny were educated by each other and learnt from each other.

- Contemporariness: that does not mean the two grammarians are in the same class, for example, Sebaweeh (d. 180 AH) and Younis Ibn Habeeb (d. 182 AH), and others.

- The geographical position and the grammar school: this is an internal classification in the same class. For instance, we may classify the class into Basrioon and Koufioon.

\section{APPlying The NeW Standards in Classification}

Depending on the re-examination and re-analysis of historical narratives, the researcher has found the following:

First: there are not partners with Abu Al-Aswad Al-Dou'aly in establishing the grammatology. Strictly speaking, those who became baffled by the uncertainties of who was the founder ultimately concluded that Abu Al-Aswad was the founder.

Second: the studentship should be the backbone of the classification, which will distinguish between the grammarians, because of the constancy of the criterion, and we can employ other supporting standards but not as the main criterion. Personally, I tend to the opinion of Dr. Abed Al-aal Salim Moukaram which is that the date of death is not a decisive standard in the historical chronology for the grammarians. ${ }^{15}$

Third: The Classes' Sheikhs and the New Classification:

The First Class: it includes the students of the Abu-Al-Aswad Al-Dou'aly:

Nasr Bin Asem Al-Lythy, Abu Harb Bin Abi Al-Aswad, Abed Al-Rahman Bin Hermez, Anbasa AlFeel, Mymoun Al-Aqran, Yahya Bin Yamr Al-Adwany, Ibn Bareeda, Omar follower of Ghefra, and Said Bin Abed Al-Rahman Bin Rqesh.

Their contributions to grammatology vary between the grammarians in this class. Nasr Bin Asem AlLythy, Yahya Bin Yamr, Mymoun, and Anbasa lead this class. The biography books do not mention any noticeable contribution by the others, and some of them left Iraq to another country.

\section{The Most Famous Leading Authorities in this Class}

\section{- Anbasa and Mymoun}

The historical references talk about their distinction and contribution to the grammatology; both of them are the students of Abu Al-Aswad Al-Dou'aly ${ }^{16}$. There are some clarities in Anbasa's biography, but there is vagueness in Mymoun's biography. Abdallah Ibn Isaac studied under them, and Zouhair Bin Mumoun Al-Fargby Al-Nahwy Al-Kufy (d. 155 AH) the sheikh of Al-Rou'asy, was educated by Mymoun. ${ }^{17}$

The writer of Nozhat Al-Albaa said that Mymoun studied under Anbasa Al-Feel. ${ }^{18}$

\section{- Yahya Bin Yamr (d. 129 AH)}

He was educated by Abu -Al-Aswad. ${ }^{19}$ The narratives about his death date were different from each other; Khaleefa said, "Yahya Bin Yamr died before he was 90 years old"20 it was alleged that he died in $129 \mathrm{AH}^{21}$

\footnotetext{
${ }^{15}$ Al-Hala Al-Mafqouda fi Tareekh Al-Nahw, p 73, Al-Balagha. P 317

${ }^{16}$ Marateb Al-Nahwieen, p 11

${ }^{17}$ Inbah Al-Rewaa,2/ 18-19

${ }^{18}$ Nozahat Al-Albaa, p 302

${ }^{19}$ Marateb Al-Nahwieen: p11, / Bougayat Al-Weaa 2/345, Syar Alam Al-Noublaa: 4/442

${ }^{20}$ Marefat Al-Quraa Al-Kebar, 1/68

${ }^{21}$ Al-Balagha: 317
} 
Abu Amro Bin Al-Alaa and Abed Allah Bin Abi Isaac Al-Hadrmy learnt from Bin Yamr and they read the grammar knowledge under his observation ${ }^{22}$. Basra school does not consider him as a grammarian but a Quran reader ${ }^{23}$.

\section{- Nasr Bin Asem ( d. 89 AH)}

He narrated about Quran and grammar from Abu Al-Aswad. It was alleged that he studied under Yahya Bin Yamr Al-Adwany. ${ }^{24}$

Al-Dany said about his students, "fortuitously Abed Allah Bin Abi Isaac Al-Hadrmy and Abu Amro Bin Al-Alaa narrated the recitsion from him." 25

\section{- Abed Al-Rahman Bin Hermez}

He studied under Abu Horaira, Ibn Abbas, and Ibn Ayash; he was educated by Abu Al-Aswad, who was the first one who established grammar in Al-Madina. He died in Alexandria in $117 \mathrm{AH}^{26}$; therefore, he must be placed an a class after the class of Abu Al-Aswad unlike what Al-Zobydy did he put him and Abu Al-Aswad in one class ${ }^{27}$. For being away from Baghdad and being in Egypt, he was dropped from the classes of Basra and Kufa.

The second class: it includes two famous grammarians; the historical references asserted that they were educated by the grammarians of the first class. They are Abed Allah Bin Abi Isaac and Abu Amro Bin Al-Alaa. ${ }^{28}$

In this classification, I agree with what Said Al-Afghany wrote in his book - Tareekh Al-Nahw- ${ }^{29}$ and I disagree with him in placing Isaa Bin Omar in this class ${ }^{30}$, because this is opposed to the studentship standard which is the main base for classification, and from which the fame, the age and the school ... etc stem.

\section{- Abed Alah Bin Abi Isaac (39- 117 AH)}

He was educated buy Mymoun Al-Agran ${ }^{31}$ and Yahya Bin Yamr.$^{32}$ Ibn Abi Isaac said, “I studied the quran recitation under the Nasr Bin Asem and his companions ${ }^{33}$.

Al-Baghdady narrated from Al-Wahdy that Ibn Abi Isaac was one of the students of Anbasa Bin Madan, and Al-Baghdady praised him by saying that " no one of Anbasa's companions was like Abed Allah, whose name is Mymoun Al-Agran, who was confuting Al-Farazdq's sayings,so AL-Farazdq satirized him in this famous line: If Abed Allah were a follower, I would satirize ... ${ }^{34}$

The previous words are a little bit peculiar because he makes Mymoun and Abed Allah one person; most of the biography books separated between the two personalities. ${ }^{35}$ For example, Abu Al-Tayb Al-Loughwey said, "Mymoun's nickname was Abed Allah ... then he died and no one of his

\footnotetext{
${ }^{22}$ Marefat Al-Quraa Al-Kebar: 1/67

${ }^{23}$ Marateb Al-Nahwieen: 25

${ }^{24}$ Boughyat Al-Weaa : 2/ 213-14

${ }^{25}$ Marefat Al-Quraa Al-Kebar: 1/71; Boughy Al-Weaa: 2/314

${ }^{26}$ Marefat Al-Quraa Al-Kebar: 1/77-8 ; Inbah Al-Rewaa: 2/173

${ }^{27}$ Tabaqat Al-Nahawieen wa Al-Loughawieen: 26

${ }^{28}$ Ghurar Al-Khasa'es Al-Wadeha Wa Qurar Al-Naga'ed Al-Fadeha: 249

${ }^{29}$ Min Tareekh Al-Nahw Al-Arbi: 36

${ }^{30}$ Min Tareekh Al-Nahw Al-Arbi: 37

${ }^{31}$ Al-Fadel: 5

${ }^{32}$ Marefat Al-Quraa Al-Kebar: 1/67; Marateb Al-Nahawieen : 13

${ }^{33}$ Tareekh Demashq: 67/106; Marefat Al-Quraa Al-Kebar: 1/67; Marateb Al-Nahawieen: 13

${ }^{34}$ Khazanat Al-Adab: 1/237-238; Akhbar Al-Nahawieen:21-22

${ }^{35}$ Akhbar Al-Nahawieen Al-Basrieen: p 19-20
} 
companions was like Abed Allah Bin Abi Isaac." ${ }^{36}$ But the contexts support what Al-Baghdady narrated from Al-Wahdy, and from Abi Bakr Bin Al-Saraj, the historian, in the absence of the clear biography for Mymioun A-Agran in the biography books, the literary books, and hadith books. In addition, that age was when Abu Al-Aswad and his companions educated the grammarians, so the death date of Ibn Abi Isaac was compatible with the end of the class of Abu Al-Aswad and his students.

There were many who narrated from him. Also, Younis ${ }^{37}$, Issa Bin Omar Al-Thaqfy ${ }^{38}$ and Abu Al-Khatab Al-Khfash ${ }^{39}$ studied under him.

Most of biographers have agreed on his death date 117 AH. However, the author of Nour Al-Qabas said, "Ibn Abi Isaac died before 130 AH." 40

\section{- Abu Amro Ibn Al-Alaa ( 70-154 AH )}

$\mathrm{He}$ was born in Makkah in $70 \mathrm{AH}$; some said he was born in $68 \mathrm{AH}$ and some in $65 \mathrm{AH}{ }^{41} \mathrm{He}$ travelled to Basra and Kufa and studied Quran and grammar under the sheikhs of Basra.

He was educated by the leading grammarians of the first class. Ibn Asaker said Ibn Al-Alaa was educated by Yahya Ibn Yamr ${ }^{42}$, and more than one, for example, Al-Serafy and Al-Syooty, said Ibn Al-Alaa studied under Nasr Bin Asem ${ }^{43}$, but Ibn Asaker wrote the opposite: he asserted that Ibn Al-Alaa said, "I did not study under Nasr Bin Asem and his companions but under Al-Hijaz sheikhs." ${ }^{44}$ I do not think he studied under Nasr for a long time because Nasr died in 89 AH and the birth date of Abn Al-Alaa was in $70 \mathrm{AH}$.

And if we assume that he started studing when he was 15 years old, the four years with Nasr are not sufficient.

Ibn Khalekan thought that he should be placed in the grammar fourth class after Ali Ibn Taleb (May Allah Be Pleased With Him) ${ }^{45}$, and there was a group of sheikhs of recitation at his age in Basra, but they did not meet him, for example, Abed Allah Ibn Abi Isaac. ${ }^{46}$ Ibn Khalekan was approaching them together, so it was said that After Mymoun came Anbasa Bin Madan who in turn enriched what he had studied, and then in one age Abed Allah Bin Abi Isaac appeared. ${ }^{47}$ Al-Khaleel said, " Abed Allah surpassed Abi Amro in grammar, and Abo Amro surpassed him in language." "48 Ibn Abi Isaac died before Abu Amro. ${ }^{49}$

However, Al-Zobydy differentiated between them in Tabaqat Al-Nahwieen, and Al-Baghdady in Al-Khazana by narrating it from Al-Wahdy . Both of them made Ibn Abi Isaac the sheikh of Abu Amro in grammar ${ }^{50}$, and Al-Samre'ay said so: he and Issa studied under Ibn Abi Isaac. ${ }^{51}$

\footnotetext{
${ }^{36}$ Marateb Al-Nahawieen : p 12

${ }^{37}$ Al-Mowashah: p13 ; Khazanat Al-Adab: 1/237

${ }^{38}$ Mou'jam Al-Odabaa: 4/2141

${ }^{39}$ Khazanat Al-Adab:1/237

${ }^{40}$ Nour Al-Qabas: 25

${ }^{41}$ Wa fayat Al-Ayan: 3/469

${ }^{42}$ Tareekh Demashq:67/106; Marefat Al-Quraa Al-Kebar: 1/67,101

${ }^{43}$ Marefat Al-Quraa Al-Kebar: 1/71, 101; Boughy Al-Weaa: 2/314,Akhbar Al-Nahawieen: 17

${ }^{44}$ Tareekh Demashq: 67/107

${ }^{45}$ Wafayat Al-Ayan: 3/466

${ }^{46}$ Tareekh Demashq: 67/109

${ }^{47}$ Al-Mathal Al-Saer:1/43; Marateb Al-Nahawieen:13

${ }^{48}$ Marateb Al-Nahawieen: 14

${ }^{49}$ Akhbar Al-Nahawieen Al-Basrieen: 20

${ }^{50}$ Tabaqat Al-Nahawieen wa Al-Loughawieen:35; Khazanat Al-Adab: 1/237
} 
That is very strange: how Ibn Abi Isaac was palced in the same class with Issa Ibn Omar (d. $149 \mathrm{AH})$ and Abu Amron Ibn Al-Alaa (d. $154 \mathrm{AH})$ !!

There were many students who were educated by Abu Al-Alaa: Issa Ibn Omar, Younis Ibn Habeeb, Al-Khfash Abu Al-Khatab, and Abu Jafar Al-Rou'asy. ${ }^{52}$

The Third class: it included the students of Ibn Abi Issac and Ibn Al-Alaa: Al-Khfash, Isaa, Younis, Aby Zayd, Abu Obida , and Al-Asmay. ${ }^{53}$

The historical accounts proved the studentship of this class under Ibn Abi Isaac and Ibn Al-Alaa: every student has its own sheikh, either Ibn Abi Isaac or Abu Al-Alaa. This class is divided into sheikhs and students. We place the sheikhs class, for example, Al-Khfash, Isaa, and Younis, before the students class.

\section{- Al-Khfash Al-Kabeer or Al-Akbar, Abed Al-Hameed Abed Al-Majeed}

His death date is not known, but the historians said it was approximated to between $171 \mathrm{AH}$ and 180 $\mathrm{AH}$, and it was alleged it was $177 \mathrm{AH}$. He is the follower of Bny Qais. ${ }^{54}$ The author of Nour Al-Qabas stated that, " of students of Ibn Abi Isaac were Younis and Isaa." ${ }^{, 5}$ The researcher relies upon the story of the clarity of the Al-Khfash's class and the supremacy of Ibn Al-Alaa, which was narrated by Abu Obida. It is about that Al-Khfash told Abu Amro a verse of a poem, but Abo Amro accused him of tasheef (misstatement). ${ }^{56}$ That was asserted by Al-Hamawy and Al-Safdy ; " he met with the Bedouins and studied under them and under Abu Amro Ibn Al-Alaa and his class.. ${ }^{, 57}$ Al-Syouty ${ }^{58}$ and the author of Nour Al-Qabs approved that, and it was alleged that "He and Khalaf Al-Ahmar studied under Abu Amro Ibn Al-Alaa." $" 59$

The Yamni narrated from Yousef Ibn Yaqoup Al-Sekket from Al-Jammaz who said, "he is in the class of Isaa Ibn Yamr and Yonis."

Of his students are Sebaweeh Abu Obida Mouamr Bin Al-Mouthna ${ }^{61}$ and Al-Kesaey. ${ }^{62}$

Strangely, Al-Dahbi and others said that Isaa Ibn Omar (d. 149 AH) were educated by him! ${ }^{63}$

- Issa Bin Omar: he was classified in this class because he was educated by Ibn Abi Isaac, ${ }^{64}$ and Al-Kjhaleel was his student. ${ }^{65}$ Also, Sebaweeh was particularly attributed to Al-Khaleel. Because of that fact that he was not educated by Ibn ABI Isaac, he was not placed in the same class with his own sheikh. Al-Hamawy transmited what Al-Mobarad had said:Isaa studied the grammar under Abu Amro Bin Al-Alaa. ${ }^{66}$

\footnotetext{
${ }^{51}$ Al-Mofeed fi Al-Madares Al-Nahawya: 47-49

${ }^{52}$ Marateb Al-Nahawieen:21-24

${ }^{53}$ Marateb Al-Nahawieen: 39 - 40

${ }^{54}$ Syar Alam Al-Noublaa:7/323; Tareekh Al-Isalm:4/772; Diwan Al-Islam: 1/48; Al-Nojom Al-Zahera:2/111; Al-Alam: 3/288

${ }^{55}$ Nour Al-Qabas: 47

${ }^{56}$ Tareekh Demashq:67/113

${ }^{57}$ Mou'jam Al-Odabaa: 6/2858; Al-Wafy Bilwafayat:18/49

${ }^{58}$ Boughyat Al-Weaa: $2 / 74$

${ }^{59}$ Nour Al-Qabas:47 ; Marateb Al-Nahawieen: 23

${ }^{60}$ Inbaa Al-Rwaa: $2 / 158$

${ }^{61}$ Boughyat Al-Weaa:2/74; Inbaa Al-Rewaa:2/158; Wafayat Al-Ayan: 2/310 and 380; Shathrat Al-Thahab:3/73; Syar Alam Al-Noublaa:14/482; Tareekh Al-Islam: 4/772

${ }^{62}$ Mou'jam Al-Odabaa:6/2858; Diwan Al-Isalm:1/48; Al-Wafy Bilwafayat: 18/49

${ }^{63}$ Syar Aalam Al-Noublaa:6/2858; Al-Wafy Bilwafayt:18-49; Al-Nojoum Al-Zahera: 2/111

${ }^{64}$ Al-Fadel:5; Khazanat Al-Adab:1/237; Mou'jam Al-Odaba:4/2141; Akhbar Al-Nahawieen Al-Basrieen:25; Tareekh Al-Olamaa Al-Nahawieen:135; Nozhat Al-Albaa:302

Mou'jam Al-Odabaa: 4/2141 and others ${ }^{65}$

${ }^{66}$ Mou'jam Al-Odabaa: 4/2141
} 
In his biography, Abu Al-Mahasen asserted that Issa was authorized by Abu Amro for being his student, transmitting it from Akhbaar AL-Nahwieen. ${ }^{67}$ If that had been a fact, we would have considered it another restraint on classifying him in the class of Ibn Al-Alaa and Ibn Abi Isaac.

Al-Serafy inaccurately said, "he is in the class of Abu Amron Bin Al-Alaa." ${ }^{68}$ Since he considered the death date in classification. If his criterion had been correct, we would have place Sebaweeh (d. 180 AH) in the class of Younis (d. 182 AH). Furthermore, Abu Amro and Abn Abi Isaac had been educated by the students of Abu Al-Aswad, and Issa studied under Ibn Abi Isaac. I do not think it is correct to place the sheikh and the student in one class, and I disapprove of parallelizeing between the sheikh and the student even if they have the close death date or if the sheikh died much later than his student.

Al-Afghany confirmed that Issa had studied under Abu Amro and Ibn Abi Isaac, ${ }^{69}$ and it asserted that is was not approved to insert him in the same class with his both sheikhs!

Al-Dahbi wrote that Isaa and Abu Obida had been educated by Al-Khfash Al-Akbar ${ }^{70}$, so he may be placed in a class after Al-Khash class if there are many supporting accounts about him.

He educated Al-Khaleel, the Arab genius, and he was the key of language science and its master. ${ }^{71}$

\section{- Younis Ibn Habeeb (d. 182 or 183 AH )}

He was classified in this class because he has studied under Ibn Abi Isaac for many years, ${ }^{72}$ and he narrated the recitation from Abu Amro Bin Al-Alaa; he was one of those writing for Abu Al-Alaa. ${ }^{73}$ Al-Qefty and AL-Syooty stated that he had studied under Al-Khfash Al-Akbar ${ }^{74}$,so if that had been correct, he would have been placed in a lower-than-Al-Akhfash class. Strictly speaking, that was not verified by the authors of biographies, for example, the author of Tareekh Al-OlmaaAl-Nahawieen who said, "it is alleged that Younis studied under Abi Al-Khatab, and Al-Khaleel under Abu Amro." 75

Abu Said Al-Hasan Bin Abed Allah AL-Serfay said, "Abu Amro was one of the pioneers in Quran; Younis Bin Habeeb studied under him, and he learnt the recitation, grammar and language from him. ${ }^{, 76}$ Younis was asked about Hamda Bin Salama and he said,: he is older than me and I learnt the language from him."77

Sebaweeh narrated from him, and Al-Kesaey and Al-Faraa studied under him. ${ }^{78}$

The fourth class: it includes the students if Issa Bin Omar and of Ibn Al-Alaa:

Some of the students of Abu Amro were educated by Issa, Abu Al-Khatab, Al-Akhfash, and Younis ${ }^{79}$; therefore, they were classified in this class. It also includes Abu Zayd, Abu Obida, and Al-Asmay. "All of them studied the language, the grammar, and the poetry, and they transmitted the recitation from him" ${ }^{80}$, and so did Al-Khaleel. ${ }^{81}$ The most important students are:

\footnotetext{
${ }^{67}$ Tareekh Al-Olamaa Al-Nahawieen: 15

${ }^{68}$ Akhbar Al-Nahawieen Al-Basrieen: 25

${ }^{69}$ Min TareekhAl-Nahw Al-Arabi

${ }^{70}$ Syar Aalam Al-Noublaa: 7/232

${ }^{71}$ Mou'jam Al-Odabaa"4/2141; Akhbar Al-Nahawieen Al-Basrieen:25; Marateb Al-Nahawieen: 28/29

${ }^{72}$ Al-Mowashah:130; Khazanat Al-Adab:1/237; Nour Al-Qabas:46

${ }^{73}$ Tareekh Demashq:67/109; Akhbar Al-Nahawieen Al-Basrieen:27; Marateb Al-Nahawieen:22; Nozhat Al-Albaa: 47

${ }^{74}$ Inbaa AL-Rwaa:2/157; Boughyat Al-Weaa:2/74

${ }^{75}$ Tarekh Al-Olamaa Al-Nahawieen:139

${ }^{76}$ Tareekh Demashq: 67/109; 110

${ }^{77}$ Nozhat Al-Albaa: 42

${ }^{78}$ Akhbar Al-Nahawieen Al-Basrieen:27

${ }^{79}$ Mrateb Al-Nahawieen:40

${ }^{80}$ Marateb Al-Nhawieen:39-40
} 


\section{- Al-Khaleel (d. 160 AH)}

He studied under Ibn Al-Alaa. ${ }^{82}$ The most of resources suggested that Al-Khaleel studied the grammar under Isaa, and then educated Sebaweeh ${ }^{83}$; therefore, Al-Khaleel was classified in this class.

There are a lot of students who learnt the grammar from Al-Khaleel, for example, Sebaweeh, Al-Nadr Bin Shomyl, Haroun Bin Mousa, Wahb Bin Jarer, Al-Asmay, and others. ${ }^{84}$

\section{- Abu Zyd (d. 2015 AH)}

He learnt the language, the grammar, and the poetry from Ibn Al-Alaa, and so did Abo Obida and AL-Asmay. Then they learnt from Isaa, Abu Al-Khatab Al-Khafash, and Younis. ${ }^{85}$ Abu Zayd has accompanied Younis for ten years ${ }^{86}$. Also, Sebaweeh did learn from Younis. ${ }^{87}$

\section{- Abu Obida Mou'mar Bin Al-Mothna ( b. 110 or 112 - 208 or 209 or 210 AH) ${ }^{88}$}

AL-Soyooty and others said he learnt from Al-Khfash Al-Akbar, ${ }^{89}$ and he was educationally raised by Al-Khfash. ${ }^{90}$ Moreover, it was alleged that he learnt the language, the grammar, and the poetry from Abu Amro. Then he studied under Isaa, Abu Al-Khatab Al-Khfash, and Younis. ${ }^{91} \mathrm{He}$ has accompanied Younis for forty years. ${ }^{92}$ Accordingly, he was classified in this class, and he was more famous in the genealogy and historical events than the language.

\section{- Khalaf Al-Ahmar}

He learnt the grammar from Isaa Bin Omar, and the language from Abu Amro. ${ }^{93}$ In addition, he has accompanied Younis for twenty years. ${ }^{94}$

\section{- Abu Jafar Al-Rou'asy ( Hazem or Mohammed Bin Abu Sarah) ( d. 187 AH)}

He is a Kufi, learning from Abu Amro ${ }^{95}$, and from Isaa Bin Omar ${ }^{96}$. Also, he narrated from Zouhair AL-Farqby, the student of Mymoun Al-Aqran. ${ }^{97}$

\section{- Mouaz AL-Haraa (d. 187/ 190 AH) ${ }^{98}$}

He is a Kufi, a agreat grammarian, aged 150 and some said he aged 90. He narrated from Jafar ALSadeq and Atta Bin Al-Saeb. ${ }^{99}$

\footnotetext{
${ }^{81}$ Tareekh Al-Olamaa Al-Nahawieen:139

${ }^{82}$ Tareekh Al-Olama Al-Nahawieen:139; Nozhat Al-Albaa:45

${ }^{83}$ Al-fadel:5; Tareekh Al-Olamaa Al-Nahawieen:139; Nour Al-Qabas:58; Tahtheeb Al-Kamal:8/330; Marateb Al-Nahawieen:27; Nozhat Al-Odabaa:302

${ }^{84}$ Syar Aalam Al-Noublaa:7/430

${ }^{85}$ Marateb Al-Nahawieen:39-40; Nozhat Al-Albaa:101; Syar Aalam Al-Noublaa:9/494

${ }^{86}$ Wafayat Al-Ayan:7/245

${ }^{87}$ MaratebAl-Nahawieen:42

${ }^{88}$ Nour Al-Qabas:109; Al-Balagha:295; Syar Aalam Al-Noublaa:9/447

${ }^{89}$ Boughyat Al-Weaa:2/74; Wafayat Al-Ayan:2/310;380; Tareekh Al-Isalm:4/772; Al-Balahga:179

${ }^{90}$ Nozhat Al-Albaa:44

${ }^{91}$ Mareteb Al-Nahawieen :39-40; Syar Aalam Al-Noublaa:9/445

${ }^{92}$ Wafayat Al-Ayan:7/244

${ }^{93}$ Marateb Al-Nahawieen:47

${ }^{94}$ Wafayat Al-Ayan: 7/245

${ }^{95}$ Marateb Al-Nahawieen:24; Inbaa Al-Rewaa:4/105

${ }^{96}$ Al-Balagha:105; Boughyat Al-Weaa:1/492; Tareekh Al-Olamaa Al-Nahawieen:194

${ }^{97}$ Inbaa AL-Rewaa:2/19

${ }^{98}$ Al-Alam:7/258; Nour Al-Qabas:276; Tareekh Al-Isalm:4/976
} 
I did not find a sheikh in the grammar or the language for him in all references I read, and I do not know any reason why he was classified here other than this reason: he is the first Kufi who learn the grammar, and the Al-Sarf (morphology) ${ }^{100}$ is attributed to him.Once Al-Kesaey asked who was teaching the grammar very well, the people led him to Mouaz Al-Haraa. Therefore, he accompanied him until he learnt all the knowledge from Al-Haraa. ${ }^{101} \mathrm{Also}$, Al-Faraa learn from AL-Haraa, some said. ${ }^{102}$

The source of his knowledge is not known for me, and I did not find it in the references I examined. All that is because he has lived for a very, very long time, and "he was born at the time of Yazeed Bin Abed Al-Malek, and has lived up to Al-Barameka Age. He has had many children and grand-children : all of them died except him." 103

If we apply the contemporary standard because of not identifying the sheikh, he will be classified in a class representing his awareness of the linguistics and his bringing-up. Approximately, he can be classified in the class of Abu Amro Bin Al-Alaa and Abed Allah Bin Abi Isacc, which is opposed to all the references I read because all classified him with Abu Jafar Al-Rou'asy in the first Kufi class parallelizing with the Khaleel's Basri class.

Owing to that fact that he had no famous students other than Al-Kesaey and Al-Faraa, he was classified in the class before his students'. In other words, he was affiliated with his students more than his students with him.

The fifth class: it includes the students of Al-Khaleel and those who in his class, or the students who are before him and studied under him:

\section{- Sebaweeh ( d. 180 AH)}

He learnt from Al-Khaleel, Younis, Abu Al-Khatab Al-Khfash, and Isaa Bin Omar. ${ }^{104}$

Ibn Khelekan and others said, "He, Abu Obida, and the rest of class studied under Al-Khfash Al-Akbar. ${ }^{105}$

Some alleged that he hade been educated by Abu Amro Bin Al-Alaa ( d. $154 \mathrm{AH}$ ), and we do not know the accuracy of that because we do not identify how he has accompanied Abu Al-Alaa, and how old he was. The accurate information is that he learnt from Al-Khaleel (d. $175 \mathrm{AH})$ and Younis (d. $182 \mathrm{AH}) .{ }^{106}$

Few references claimed that he studied the grammar from Isaa Bin Omar ${ }^{107}$, but that is not logical, for Sebaweeh was born in 140 or 148 AH and Ibn Omar died in 149 AH !

\section{- Al-Asma'y ( 123 - 216 AH )}

He learnt the language, the grammar, and the poetry from Abu Amro Bin Al-Alaa, and then he and his two companions learnt from Issa, Abu Al-Khatab Al-Khfash, and Younis ${ }^{108}$. In the ranks of the grammarians it is mentioned that he narrated from Al-Khaleel in more contexts ${ }^{109}$, so he was classified in a class following Al-Khaleel's.

\footnotetext{
${ }^{99}$ Boughyat Al-Weaa:2/292; Syar Aalam Al-Noublaa:8/482; Tareekh Al-Islam:4/976

${ }^{100}$ Diwan Al-Isalm: 4/131

${ }^{101}$ Nozhat Al-Albaa:59; Tareekh Al-Isalm:4/976; Tareekh AL-OLamaa Al-Nahawieen:193; Inbaa Al-Rewaa:2/258

${ }^{102}$ Inbaa Al-Rewaa:3/290

${ }^{103}$ Nozhat Al-Albaa: 50

${ }^{104}$ Boughyat Al-Weaa:2/229

${ }^{105}$ Boughyat Al-Weaa:2/74; Wafayat Al-Ayan:2/310;380; Tareekh Al-Islam:4/772; Al-Balagha:179

${ }^{106}$ Al-Ketab:3/242; Marateb AL-Nahawieen:65; Nozhat Al-Albaa:45,47,55

${ }^{107}$ Nozhat Al-Albaa: 55; Boughyat Al-Waa:2/229

${ }^{108}$ Marateb Al-Nahwieen:39; Nozhat Al-Albaa:35,48

${ }^{109}$ Marateb Al-Nhawieen:34-65; Nozhat Al-Albaa:31
} 


\section{- Al-Nadr Bin Shomyl (d. 203 or 204 AH )}

He studied the language and the grammar under Al-Khaleel. ${ }^{110}$

\section{- Al-Yazeedy Yahya Bin Al-Moubarak ( d. 202 AH)}

He learnt the language and the grammar from Al-Khaleel, and before AL-Khaleel and, without any doubts he studied the language and the recitation from Abu Amro, and he learnt from Ibn Abi Isaac. ${ }^{111}$ We classified him in this class because he studied under Al-Khaleel, and he recited the Quran for the people with Al-Kesaey in one masjid. ${ }^{112}$

\section{- Mou'raj Bin Amro Al-Sadousy ( d. 195 AH)}

He learnrt from Al-Khaleel, ${ }^{113}$ and he was one of his best students. Also, he was educated by Abu Amro, and he learnt the al-qias (analogy) from Abu Zayd Al-Ansary. ${ }^{114}$

\section{- Al-Kesaey ( d. 189 AH )}

He is a Kufi, studying under Al-Khfash Al-Akbar ${ }^{115}$, Abu Amro, Younis, and Isaa ${ }^{116}$. He studied the language under Al-Kaleel. ${ }^{117}$ Moreover, he was educated by Mouaz Al-Haraa, and both of Al-Kesaey and Al-Faraa studied under Al-Rou'asy. ${ }^{118}$

\section{- Abu Amro Al-Shybany, Isacc( d. 206 or 210 or 213 AH )}

He is a Kufi, and he was one of the elite kufis in the Arabic language and he narrated from the trusted Bedouins more than any linguists in Kufa. ${ }^{119}$ It is said about him, "He is the Sheikh of Arabic; Ahmed Bin Hanbal Narrated from him." ${ }^{120}$ In addition, Al-Hamawy wote in his Mou'jam that he was one of the most intelligent linguists and he wrote many books about language. ${ }^{121} \mathrm{He}$ died at the age of one hundred and eight or one hundred and nineteen. ${ }^{122}$

We classified him in this class before his closest famous students: Al-Lehyany and Ibn Al-Sekeet as we did with Mouaz Al-Haraa. He and Mouaz AL-Haraa had the same long age, and their language sheikhs are unknown. On the other hand, the historical books mentioned about their efforts in the language.

The sixth class: it includes all students of the grammarians in the previous class. The most important students are:

\section{- Al-Khfash, Said Bin Masada}

"He learnt the grammar from Sebaweeh who is not as old as Al-Akhfash. He learnt from whom Sebaweeh studied under, and that means this is the way to Sebaweeh's Book ${ }^{123}$. Also, he was the

\footnotetext{
${ }^{110}$ Marateb Al-Nahawieen:66; Nozhat Al-Albaa: 45, 73

${ }^{111}$ Marateb Al-Nahawieen: 66-67; Nozhat Al-albaa:69; Tareekh Al-Islam:5/226

${ }^{112}$ Tareekh Al-Islam: 5/226

${ }^{113}$ Marateb Al-Nahawieen:67; Nozhat Al-Albaa:45; Al-Balagha:299; Wafayat Al-Ayan:5/306; Tareekh Al-Islam:4/355

Boughyat Al-Weaa:2/305; Nozhat Al-Albaa: 105; Tareekh Al-Islam:4/1219-1220 114

${ }^{115}$ Boughyat Al-Weaa:2/74

${ }^{116}$ Nozhat Al-Albaa:47; Akhbar Al-Nahawieen Al-Basrieen: 44

${ }^{117}$ Marefat Al-Quraa Al-Kebar: 1/120; Nozhat Al-Albaa:59

${ }^{118}$ Nozhat Al-Albaa:50,28;Nour Al-Qabas:179, 276; Inbaa Al-Rewaa:4/107; Alwafy Bilwafayat:248

${ }^{119}$ Marateb Al-Nahawieen:91

${ }^{120}$ Lesan Al-Mizan:3/476; Mou'jam Al-Odabaa:2/626

${ }^{121}$ Mou'jam Al-Odabaa: 2/625

${ }^{122}$ Nour Al-Qabas:278; Nozhat Al-Albaa:80

${ }^{123}$ Marateb Al-Nahawieen:68; Nozhat Al-Albaa:57, 107-108
} 
educator of Al-Kesaey's son." ${ }^{124}$ But the historians did not agree on his companionship with AlKhaleel: the writer of Inbaa Al-Rewaa stressed that he learn from Al-Khaleel, but the writer of Marateb Al-Nahawieen stressed he did not learn from him. ${ }^{125}$

- Qoutrob, Mohammed Bin Al-Mostaneer (d. 20 AH)

He studied under Sebaweeh ${ }^{126}$ and Younis Bin Habeeb. ${ }^{127}$

- Ali Bin Al-Moubarak, Al-Ahmar ( d. 194/206/207 AH)

$\mathrm{He}$ is a Kufi, learning from Al-Kesaey. He is in the class of Ibn Said Al-Amawy, and he preceded AlFaraa and died before him. ${ }^{128}$ According to Inbaa Al-Rewaa, Al-Ahmar studied under Al-Rou'asy , then under AL-Kesaey for a very long time. ${ }^{129}$

\section{- Al-Faraa (d. 207 AH )}

He is a Kufi, studying under Al-Kesaey, who he depended on in the grammar, and the Bedouins, and learning a little from Younis. ${ }^{130}$ Also, He and Al-Kesaey were educated by Abu Jafar Al-Rou'asy. ${ }^{131}$

\section{- Hisham Bin Mouaya Al-Dareer, Abu Abed Allah (D. 209 AH)}

He is a Kufi, learning from Al-Kesaey. ${ }^{132}$

\section{- Abed Allah Bin Said Al-Amawy Al-Loughawy ( d. 201 or 210 AH )}

He is a Kufi, leaning from the Bedouins and Abu Jaffar Al-Rou'asy and a little from Al-Kesaey. ${ }^{133}$

\section{- Ali Bin Al-Moubarak (Ibn Hazem) Al-Lehyany, Abu Al-Hasan}

He is a Kufi, learning from Al-Kesaey on whom he depended in the grammar. Also, he studied under Abu Zayd, Abu Obida, and AL-Asmay. Al-Seyooty said, "he was educated by Abu Amro AlShybany." ${ }^{134}$ Therefore, we classified him in this class.

\section{- Ibn Sadan, Al-Dareer (the blind), Abu Jafar, ( d. 231 AH)}

$\mathrm{He}$ is a Kufi, studying under Al-Kesaey and narrating from Abu Mou'way Al-Dareer. ${ }^{135}$

The seventh class:

\section{- Al-Jouramy (d. 225 AH )}

$\mathrm{H}$ studied Al-Ketab under Al-Akhfash, learning the grammar from him and the others. Besides, he studied the language under Abu Obida, Abu Zayd, and Al-Asmay. He accompanied Younis, but he did not meet Sebaweeh. ${ }^{136}$

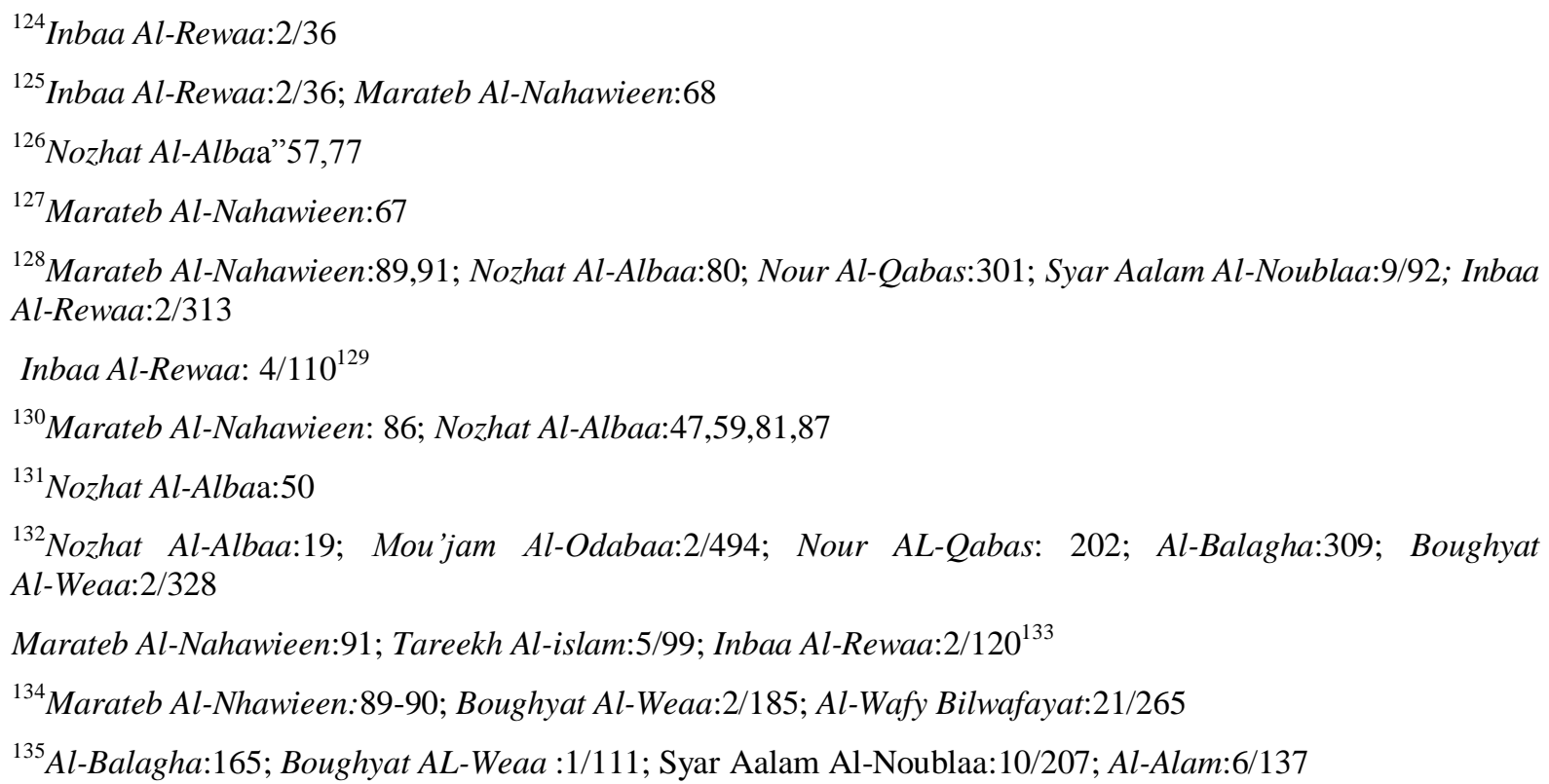




\section{- Aby Hatem Al-Sejestany ( d. 248/254 AH)}

He studied the language, the recitation, and the grammar under Al-Akhfash Al-Awsat. ${ }^{137}$ Also, he narrated from Abu Obida Moumr Bin Al-Mouthna ${ }^{138}$, and he learnt from Abu Zayd Al-Ansary. ${ }^{139}$

\section{- Abu Othman Al-Mazny (23 AH) ${ }^{140}$}

He narrated from Abu Obida Moumar Bin Al-Mouthna, Al-Asmay, and Abu Zayd. Al-Syooty said “ he learntfrom Al-Akhfash, but some said he did not learn from him but from Al-Jouramy. ${ }^{141}$ " In AlNozha and other books, it was stated that he and AL-Jouramy studied Al-Ketab under Al-Akhfash. ${ }^{142}$

\section{- Al-Ryashy, Abu Al-Fadl AL-Abbas Bin Al-Faraj (257 AH )}

He studied Al-Ketab under Al-Mazny, and he narrated from AL-Asmay ${ }^{143}$. Furthermore, Al-Mazny studied the language under him, ${ }^{144}$ so he was classified in the class of Al-Mazny because both of them were a student to each other: each one was a student and a sheikh for the other.

\section{- Al-Tawal, Abu Abed Allah, Mohammed Bin Qadem ( or Ibn Ahmed ) ( d. 243 AH )}

$\mathrm{He}$ is a Kufi, one of the companions of Al-Kesaey and Al-Faraa. The references did not agree on identifying his name; Al-Zoubydy makes it two names: Al-Tawal and Ibn Qadem, but accordinf to the editor he did not biographize AL-Tawal. However, Al-Fyrozobady and Al-Tanokhy explained that the two names were for one person; it is said that his name was either Ahmed Bin Abed Allah or Ibn Obid Allah Bin Qadem, who was the sheikh of Thalaba. ${ }^{145}$

\section{- Ibn Al-Araby, Mohammed Bin Zyad ( d. 231 AH)}

He is a Kufi. He learnt the grammar from AL-Kesaey, and he studied under Bany Asad and Bany Oqail. Also, he was raised by Al-Mofadal Al-Daby and learnt from him. ${ }^{146}$

\section{- Yaqoub Bin Al-Sekeet, Abu Yousef. ( 243 or 244 AH)}

$\mathrm{He}$ is a Kufi. He and Thalab were the great inheritors of the Kufi grammar. He was one of Al-Kesaey's students, and some said he was his father. ${ }^{147}$ When Al-Kesaey died, the companions of Al-Faraa assembled and ask him to teach them; Bin Al-Sekeet was amongst those who asked him about his ancestors ${ }^{148} \mathrm{He}$ learnt from Al-Faraa, and Abu Amro Al-Shybany. ${ }^{149}$

Because he studied under Al-Faraa, he was classified in this class. Also, he studied under Al-Basrioon, for example, Al-Asmay, Abu Obida, and Abu Zayd, but it was said that he learnt from them without listening to them directly. ${ }^{150}$

${ }^{136}$ Akhbar Al-Nahawieen Al-Basrieen:39,56; Al-Balagha:155; Boughyat Al-Weaa:2/8; Syar Aalam AlNoublaa:10/562; Nozhat Al-Albaa: 114

${ }^{137}$ Marateb Al-Nahawieen:80

${ }^{138}$ Wafayat Al-Ayan:5/235-236; Nozhat Al-Albaa:86

${ }^{139}$ Nozhat Al-Albaa: 101

${ }^{140}$ Nour Al-Qabas:220

${ }^{141}$ Syar Aalam Al-Noublaa:9/446; Wafayat Al-Ayan:5/235-236; Nozhat Al-Albaa:86; Boughyat Al-Weaa:1/463464

${ }^{142}$ Nozhat Al-Albaa:108; Tareekh Al-Olamaa Al-Nahawieen:86

${ }^{143}$ Nour Al-Qabas:220; Al-Balagha:164; Tareekh Al-Islam:6/99; Nozhat Al-Albaa:153; Inbaa Al-Rewaa:2/368

${ }^{144}$ Boughyat Al-Weaa:2/27; Al-Wafy Bilwafayat:16/373; Mou'jam Al-Odaba:4/1483

${ }^{145}$ Boughyat Al-Weaa:1/50; Inbaa Al-Rewaa:2/92; Al-Balagha:281; Tabaqat Al-Nouhat 137-138; Tareekh Al-Olamaa Al-Nahawieen: 183

${ }^{146}$ Syar Aalam Al-Noublaa:10/688; Nozhat Al-Albaa:120

${ }^{147}$ Wafayat Al-Ayan:6/398; Mou'jam Al-Odaba:6/2840

${ }^{148}$ Inbaa Al-Rewaa:1/255; 4/57

${ }^{149}$ Nozhat Al-Albaa:138; Mou'jam Al-Odabaa:6/2840; Wafayat AL-Ayan:6/395; Syar Aalam Al-Noublaa:12/16; Tareekh Al-Olamaa Al-Nahawieen:201

${ }^{150}$ Marateb Al-Nahawieen:95; Mou'jam Al-Odabaa:6/2840; Boughyat AL-Weaa:2/349; Wafayat Al-Ayan:6/395 
- Salama Bin Asem, Abu Mohammed Al-Nahwy ( 231 - 240 AH)

He is a Kufi, studying under Al-Faraa, and he narrated his books. Also, he learnt from Khalaf Al-Ahmar, and then Thalab studied under Ibn Asem. ${ }^{151}$

\section{The eight class:}

\section{- Al-Touazy ( Al-Touji), Abu Mohammed, Abed Allah Bin Mohammed ( d. 233 or 28 AH)}

He studied under Abu Obida Mouamr Bin Al-Mouthna, Al-Asmay and Abu Zayd. Also, he studied Al-Ketab under Abu Omar AL-Jouramy. ${ }^{152}$, so we classified him in a class following Al-Jouramy's, yet the most classified him in the class of Al-Mazny and Al-Jouramy owing to the contemporariness and death date.

\section{- Al-Moubarad (b 210 - d. 285 AH )}

He studied the grammar under Al-Mazny, Al-Jouramy, Abu Hatem Al-Sejestany; he relied much on Al-Mazny in the grammar ${ }^{153}$. Also, it is claimed that Al-Reyashy was educated by him. ${ }^{154}$

\section{- Thalab, Abu Al-Abbas, Ahmed Ibn Yahya ( 200 - 291 AH )}

$\mathrm{He}$ is a Kufi, he and Ibn Al-Sekeet were the real great inheritors of Kufi grammar. ${ }^{155} \mathrm{He}$ learnt from Al-Tawal who was his sheikh ${ }^{156}$, and he accompanied Ibn Al-Araby for nineteen years, ${ }^{157}$ then studying under Ali Bin Al-Mougheera Al-Thram, Al-Jomahy, Salama Bin Asem, ${ }^{158}$ Ahmed Bin Ibrahem Al-Masri, and Abu Nasr Al-Nahwy- the companion of Al-Asmay. ${ }^{159}$

\section{THE OUTCOMES AND THE RECOMMENDATIONS}

Thanks to Allah and His Blessings, the researcher has figured out the following points:

1. The references did not consider stable standards in classifying the Basri and Kufi grammarians; if there were stable standards, they would not be applied very well.

2. The early and late historians get confused when they come to apply their criteria, for example, the contemporariness, the fame, ... etc, for many reasons. Said Al-Fghany is the best one who managed to employ them.

3. The researcher has encountered some historical problems in the studentship of some grammarian under sheikhs related to them, for instance, the studentship of Sebaweeh under Isaa Bin Omar and Abu Amro Bin Al-Alaa, or the studentship of Isaa Bin Omar under Al-Khfash Al-Akbar; there are others who have no known sheikh, for example, Al-Shybany and Mouaaz Al-Haraa.

4. The references attach importance to the biography of the famous, the events, and situations in their lives taking the historical chronology, the knowledge rankship, the fame, or the school into consideration.

5. The researcher agrees with the previous historians in classifying some grammarians and disagrees with them in other classifications that disregard some standards due to the contemporariness, and the school; he a adopts a new classification that relies on the studentship as a base for classifying the grammarians, and he resorted to the historical accounts which bolster his classification.

\footnotetext{
${ }^{151}$ Nozhat Al-Albaa::117; Mou'jam Al-Odabaa:1/484; Boughyat Al-Weaa:1/596; Syar Aalam Al-Noubalaa:14/362; Al-Alam:3/111; Tareekh Al-Islam:5/828

Al-Kashef:2/282; Akhbar Al-Nahawieen Al-Basrieen:65; Nozhat Al-Albaa:15; Boughyat Al-Weaa:2/61; Inbaa Al-Rewaa:2/162; Mou'jam Al-Odabaa:4/1546 ${ }^{152}$

${ }^{153}$ Marateb AL-Nahawieen:8; Tareekh Al-Islam:6/831; Nozhat Al-Albaa:164; Tareekh Demashq:56/250; Boughyat Al-Weaa:1/269

Syar Aalam Al-Noublaa:12/374; Boughyat Al-Weaa:2/27 $7^{154}$

${ }^{155}$ Marateb Al-Nahawieen:95

Al-Balagha ${ }^{156}$

${ }^{157}$ Syar Aalam Al-Noublaa:10/688,14/6; Wafayat Al-Ayan:1/102; Nozhat Al-Albaa:120

${ }^{158}$ Nozhat Al-Albaa:117;,126,173; Inbaa Al-Rewaa:2/56

${ }^{159}$ Inbaa Al-Rewaa: $1 / 60,71$
} 


\section{Dr. Basem Abed Al-Rahman Al-Bably}

6. The researcher has identified standards for classification based on the studentship; he applied it to reach the final arrangement for the most famous Basri and Kufi grammarian classes, fixing some gaps through rectifying those standards by extra determiners:

a. The student does not transcend his teacher, which is the main standard of classes. "The fame of the grammarian is represented by the large amounts of his books and of the narrations sourced to him" ${ }^{160}$.Learning and knowledge transmission from the teacher is the root of the studentship and classification standard.

b. Two students should not be placed in one class if one of them is a teacher of the other such as the grammarians of the third class: Al-Khfash, Younis, and Isaa, and the grammarians of the fourth class: Al-Khlaleel, Abu Zayd, and Al-Asmay.

c. A sheikh and a student of another sheikh (who is at the same class of that sheikh) do not come together in one class like Abu Amro Ibn Alaa and Issa Ibn Omar, the student of Ibn Abi Isaac, because Abu Amro and Ibn Abi Issac ( the sheikh of Issa ) are in the same class.

d. If the sheik of any grammarian is not known, those grammarians should be classified in a class before the class of their famous students. For example, Mou'az Al-Haraa has unknown sheikh, so he was placed in a class before Al-Kesaey Class.

e. If the grammariansbecome the student andthe teacher at the same time, they will be classified in one class unless there is another standard that might distinguish between them. For instance, Al-Ryashy and Al-Mazny were educated by each other and learnt from each other.

The following table summarizes all of the classes:

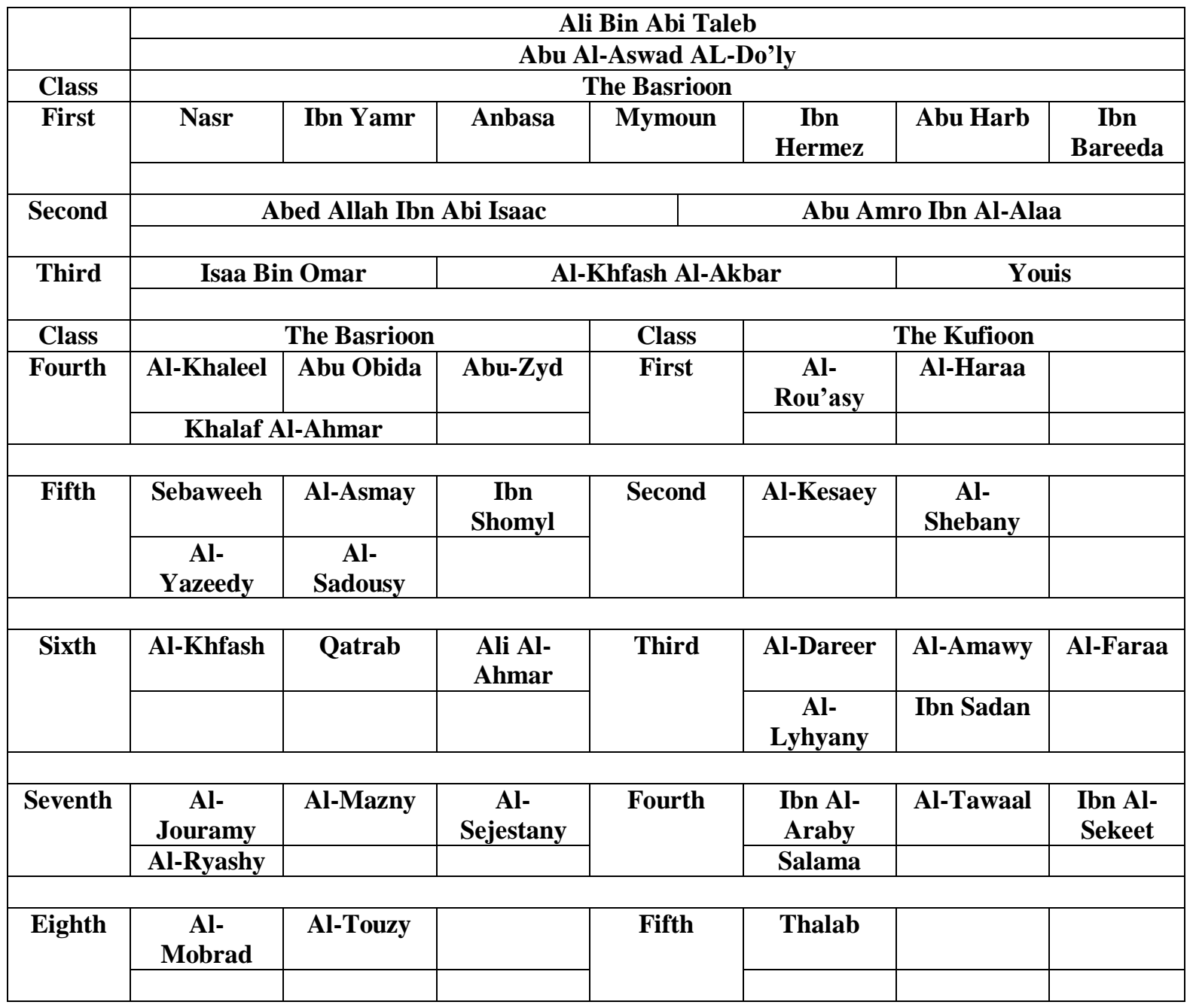

${ }^{160}$ Marateb Al-Nahwieen, p 85 


\section{REFERENCES}

[1] Bin Abedallah Al- Serafy, Al-Qday Abu Said Al-Hasan (1374AH- 1955) Akhbar Al-Nahwieen Al-Basrieen. )- Edited by Taha Mohammed Al-Zyny \& Mohammed Abed AL-Minam Khfaji. Cairo: AL-Baby Al-Hlaby Compnay.

[2] Bin Omar Bin Abi Hashem, Abu Taher Abed Al-Wahed (1413 AH - 1993) Akhbar Fi Al-Nahw. Edited by Mohammed Ahmed Al-Daly. ${ }^{\text {st }}$ ed. Qubrus:Al-Jifan \& Al-Jawaby for Bublishing.

[3] Al-Zarkly, K. (1422 AH - 2002). Al-Alam,: Qamoos Tarajim Li-Ashhar AL-rejal wa Al-Nesaa Min Al-Arab wa Al-Mostareeben wa Al-Moustashreqeen. $15^{\text {th }}$ ed. Beirut:Dar Al-Alm LilMalayeen.

[4] Bin Yousef Al-Qafty, Al-Wazeer Jammal Al-Deen Abu Al-Hasan Ali (1406 AH - 1986)Inbaa AL-Rewaa Alaa Anbaa Al-Nouhaa. $1^{\text {st }}$ ed.Cairo:Dar Al-Fikr Al-Arby.

[5] Al-Syooty, J. (1399 AH - 1979)Boughyat Al-Weaa Fin Tabaqat Al-Loughawieen Wa al-Nouhaa- Edited by Mohammed Abu Al-Fadl Ibraheem. $2^{\text {nd }}$ ed. Cairo: Dar Al-Fikr.

[6] Bin Yaqoub Al-Fyrozobady, Majd Al-Deen Mohammed. (1421 AH- 2000) Al-Balagha Fi Tarajim A'mat Al-Nahw wa Al-Lougha)- Edited by Mohammed Al-Masri. $1^{\text {st }}$ ed. Damascus: Dar Saad Al-Deen for Publishing.

[7] Bin Othman Al-Dhaby, S.(1424 AH - 2003) Tareekh Al-Islam Wa Fayat Al-Mashaheer Wa Al-Alaam-Edited by Dr. Bashar Awaad Marouf. $1^{\text {st }}$ ed. Beirut:Dar Al-Gharb Al-Islamy.

[8] Bin Mohammed Bin Masar Al-Tanoukhy Al-Mary, Al-Qady Abu Al-Mahasen Al-Mofadal.(1401 AH - 1981) Tareekh Al-Olamaa Al-Nahawien waAl-Koufieen wa AkhrounEdited by Dr. Abed Al-Fatah Mohammed Al-Holw. Saudi Arabia :Imam Muhammad ibn Saud Islamic University.

[9] Ibn Asaker, Al-Hafez Abu Al-Qasem Ali. (1415 AH - 1995). Tareekh Madeenat Demashq wa Dhekru Fadlha wa Tasmyat Man Halaha Min Al-Amathel aw Ijtaz Binawaheeha Min Waredeeha wa Aleha- Edited by: Moheb Al-Deen Abu Saad Omar Bin Gharamah Al-Amrawy. Beirut: Dar Al-Fikr.

[10] Abu Al-Hajaj Yousef Al-Mary, J. (1402 AH - 1982).Tahtheeb Al-Kamal fi Asmaa Al-Rejal - Edited by Dr. Bashar Awad Marouf. $1^{\text {st }}$ ed. Beirut: Mo'sasat Al-Resalah.

[11] Abed Al-Aal Salem Moukaram. (1413 AH - 1993) Al-Halaqa Al-Mafgouda fi Tareekh Al-Nahw Al-Araby. $2^{\text {nd }}$ ed.Beirut:Mo'sasat Al-Resalah.

[12] Bin Omar Al-Baghdady, A. (1418 AH - 1997). Khazanat Al-Adab wa Lob Lebab Lisan Al-Arab.- Edited by Abed Al-Salam Haroun $4^{\text {th }}$ ed. Cairo:Al-Khanji Library.

[13] Bin Abed Al-Rahamn Ibn Al-Ghouzy, S. (1411 AH - 1990). Diwan Al-Islam- Edited by Sayyd Kasrawy Hasan $-1^{\text {st }}$ ed. Beirutt: Dar Al-Koutb Al-Almya.

[14] Bin Othman Al-Dhahby, S. (1401 AH - 1981) Syar Aalam Al-Noublaa- Edited by Shoayb A-Rna'oot $-2^{\text {nd }}$ ed. Beirut: Mou'sasat Al-Resalah.

[15] Bin Mohammed Al-Akry Al-Hanbly Al-Demashqy, S. (1408 AH - 1988).Shathrat Al-Dhab fi Akhbar min Dhab )- Edited by Mahmoud Al-Rna'oot - $1^{\text {st }}$ ed.Damascus and Beirut: Dar Ibn Katheer.

[16] Ibn Gady Shouhba Al-Asdy Al-Shafay, T. (1974) Tabaqat Al-Nouha Wa Al-LoughawieenEdited by Mohsin Ghyad.Baghdad: Univeraisty of Baghdad \& Noaman Press.

[17] Abu Souliman, S \& Ismael, A.Tabaqat Al-Nahawieen wa Al-Loughawieen :Analytical Study. Rectified research.

[18] Bin Al-Hasan Al-Zoubydy Al-Andalossy, M. (1404 AH - 1984) Tabaqat Al-Nahawieen wa Al-loughawieen - Edited by Mohammed Abu Al-Fadl Ibraheem $-2^{\text {nd }}$ ed. Cairo: Dar Al-Ma'ref.

[19] Bin Yahya Al-Kataby (aka Al-Watwat), J. (1429 AH - 2008)Ghourar Al-Khasa'es Al-Wadeha wa Aorar Al-Nga'd Al-Fadeha- Edited by Ibraheem Shams Al-Deen $-1^{\text {st }}$ ed. Lebanon: Dar Al-Koutb Al-Almya.

[20] Bin Yazeed Al-Moubrad, M. (1414 AH - 1995) Al-Fadel- Edited by Abed AL-Azeez Al-Mymny $-2^{\text {nd }}$ ed. Cairo: Dar Al-Koutb Al-Masriya. 
[21] Bin Ahmed Al-Dhaby Al-Demashqy, S. (1413 AH - 1992) Al-Kashef fi Marefat Man Lahu Rewayat fi Al-Kotob Al-Sita)- Edited by Mohammed Awama \& Ahmed Mohammed AL-Khateeb $-1^{\text {st }}$ ed. Jeddah: Dar Al-Qibla Lithaqafa Al-Islamya.

[22] Bin Qanbr, Sebaweeh. (1408 AH - 1988) Al-Ketab-Edited by Abed Al-Salam Haroun - $3^{\text {rd }}$ ed. Cairo: Al-Khanji Library.

[23] Bin Hajr Al-Asqalany, A. (1423 AH - 2002) Lisan Al-Mizan- Edited by Dr. Abed Al-Fatah Abu Ghada: Beirut:Maktabat AL-Matboat Al-Islamya Wa Dar Al-Basha'e Al-Islamya.

[24] Bin Al-Atheer, D. Al-Mathl Al-Saer fi Adab Al-Kateb wa Al-Shaer.)-Edited by Ahmed Al-Houfy $\&$ Badawy Tabana. Cairo: Dar Nahdat Misr for Publishing.

[25] AL-Houdythy, K. (1422 AH - 2001)Al-Madares Al-Nahawya. $3^{\text {rd }}$ ed. Jordan: Dar Al-Amal; Baghdad: Maktabat Al-Lougha Al-Arabya.

[26] Deif, S. Al-Madares Al-Nahawiya. $7^{\text {th }}$ ed. Cairo: Dar Al-Maref.

[27] Bin Ali Al-Loughwy Al-Halby, A. Marateb Al-Nahawieen- Edited by Mohammed Abu Al-Fadl Ibraheem. Cairo: Maktabat Nahdat Misr \& Its Press.

[28] Al-Hamawy Al-Romy, Y. (1413 AH- 1993) Mou'jam AL-Odabaa: Irshad Al-Areeb ila Marefat Al-Adeeb- Edited by Dr. Ihsan Abbas - 1st ed. Beirut: Dar Al-Gharb Al-Islamy.

[29] Bin Othman Al-Dhaby, S. (1408 AH - 1988) Marefat Al-Quraa Al-Kebar ala Al-Tabaqat wa Al-Asar- Edited by Bashar Awaad Marouf and Others - 2nd ed. Beirut: Mou'sasat Al-Resalah.

[30] AL-Fghany, S. Min Tareekh Al-Nahw. Beirut:Dar Al-Fikr.

[31] Bin Mosa Al-Merzyany, M. (1415AH - 1995) Al-Moushah fi Ma'kheth Al-Olamaa ala Al-Shoara'- Edited by Mohammed Hussain Shams Al-Deen - 1st ed. Beirut: Dar Al -Koutb Al-Zlmya.

[32] Bin Taghry Bardy Al-Atabaky, J. (1415 AH - 1995)Al-Nojom Al-Zahera fi Molouk Misrwa Al-Qahera- Edited by Mohammed Hussain Shams Al-Deen - 1st ed. Beirut: Dar Al-Kotb Al-Almya.

[33] Al-Anbary, K. (1405 AH - 1985) Nozhat Al-Albaa fi Tabaqat Al-Odabaa-Edited by Ibraheem Al-Samera'y - 3rd ed. Jordan:Maktabat Al-Manar.

[34] Bin Mahmoud Al-Hafez Al-Yaghmory, Y. (1384 AH - 1964) Nour Al-Qabas Al-Mouhktasr min Al-Mouqtabas fi Akhbar Al-Nohaa wa Al-Odabaa wa Al-Shoara' wa Al-Olama'for Abu Obid Allah Mohammed Bin Imran Al-Mourzyaty - Edited by Rodelf Zelhym - The German Orientalists Association: Albert Dietrich. Wiesbaden:Franz Steiner Publishing House.

[35] Bin Aybak Al-Safdy, S. (1420 AH - 2000)Al-Wafy Bilwafayat ) - Edited by Ahmed Al-Rna'oot and Tourky Mostafa - 1st ed. Beirut: Dar Ihyaa Al-Tourath Al-Arby.

[36] Wafayat Al-Ayan wa Anbaa Abna'Al-Zaman, Abu Al-Abbas Shams Al-Deen Ahmed Bin Mohammed Bin Abi Bakr Bin Khelikan (d. 681 AH) - Edited by Dr, Ihsan Abbas - Dar Sader Beirut 1414 AH - 1994.

[37] Bin Khelikan, S. (1414 AH - 1994) Wafayat Al-Ayan wa Anbaa Abna'Al-Zaman-Edited by Dr, Ihsan Abbas. Beirut: Dar Sader. 